にそれを研究開発活動に活かしていただければと思います。 なお，本学会に対して有益なご意見・ご提案などござい
ましたらお寄せください. 会員の皆さんに役立つ学会を目 指して鋭意検討していきたいと思います.

\title{
2010 年への思い
}

明けましておめでとうございます。今年は不景気も急速 に好転するような気がします。と言う前向きな気持ちでプ ラスチックの押出し成形加工機械を造っていきたいと思っ ています。

弊社は今年で創業四十三年目になります。この間にも 色々と大きな社会変動もありましたが，何とか今までやっ て来ることが出来ました. これも多くの皆様方のご支援の 御蔭だと感謝しております。

近年，お客様からの新しい機械装置への要請は，従来の 装置と生産性を比べて 1.5 倍以上の能力が出せ，また出来 た製品は精度も物性もよく，機械操作はデジタル制御とし て簡単に誰でも安全に操作をすることができ, そして誰が 作った製品も品質が同じになり，しかも電気エネルギー効 率も良くして省エネ対応であり, 機械の保守点検も容易に できるようにして機械寿命も長くする, というご要望が増 えています。

これらのご要望にお応え出来るような機械装置にするた めには，機械メーカーの考えている技術，知識だけではお 客様に満足をしていただける機械はなかなか出来上がらな いと思っています。

そこで私たちはお客様から現状の問題点をいろいろとお 尋ねして, その問題点についてお客様と共に何がその原因 となっているかを話し合い, 検討し, その問題解決のため の最善策を機械の設計に取り达むようにしています.

時には社内に設置してある試験機で実際に目的の製品試 作をして，その結果を基に機械の仕様を決める場合もあり

* Shinmoto, Mineo

トミー機械工業侏) 代表取締役社長

横浜市港北区綱島東 6-10-29（开223-0052）
新 本 峰 雄*

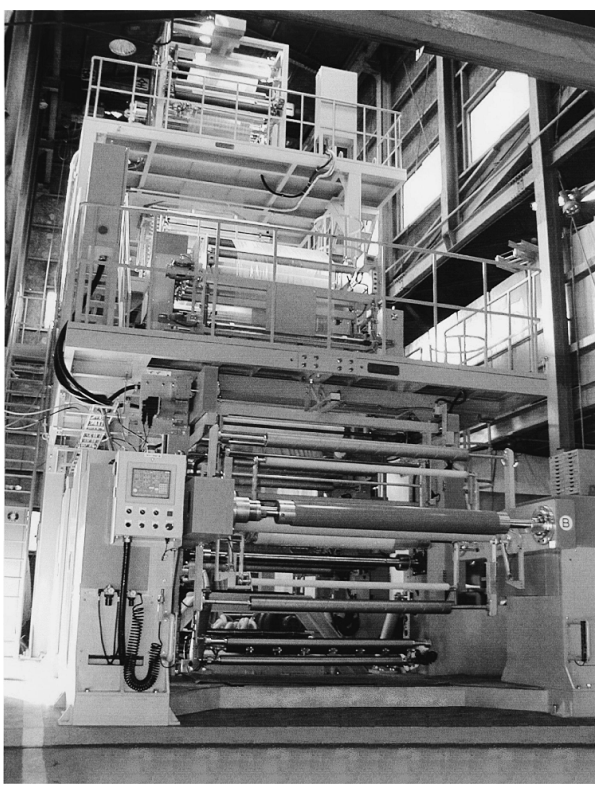

ラミ原反用フィルム製造装置

ます。

また近頃は科学技術の進歩が速く, 電子部品などは次々 に性能の良い新製品が出てきています．プラスチックも 色々な用途に適した新しい樹脂が開発されています。この ような最新の電子部品や新しい樹脂にも対応できる機械装 置を造り続けていきます.

またこれからは金融経済主体の偏った社会に振り回され ることのない, ものづくりが大切にされる, 穏やかなゆと りのある社会になってくれるように願っています.

\section{常識を超えよう！}

高 原 忠 良*

皆様，新年明けましておめでとうございます．

ちょうど 1 年前は, どこまで不況が続くのか, 暗黒に飲 み込まれるような不安とともに迎えました。今年は，まだ まだ明るい状況にはほど遠いところではありますが，薄日 が見え隠れするまでには回復してきたのではないでしょう か?

このような経済環境下，はたまた，鳩山首相が提唱する ような炭酸ガスの 90 年基準での $25 \%$ 削減に代表されるよ うな環境要請の元, 真の競争力を発揮するためのアプロー

\footnotetext{
* Takahara, Tadayoshi

トヨタ自動車(秼) 調達企画部 部品技術室 部品・工法 $1 \mathrm{Gr}$ プロジェクト・マネージャー

豊田市トヨ夕町 1 番地（テ471-8571）
}

チについて，年頭に考えてみたいと思います.

業務の関係上，中小から大手までの，数多くの成形加工 の現場を見る機会に恵まれておりますが，驚くべきほど類 似した課題に直面しているという, ご苦労の現場, まさに 生々しい生産の現場を見させていただいております。

射出成形の現場では，ヒケ・バリ・銀条・ショート・変 形で悩んでおり，ブロー成形の現場では，パリソンの形状 不安定に困っており，はたまた発泡成形の現場では，ボイ ド問題を抱え続けているといった状況です，どこの企業の 現場に行っても，同じ工法であれば，同じ「慢性不具合」 を抱えています。慢性の問題ですから, 不良が発生するこ とに慣れてしまい, 発生することが当たり前で対策は不可 能という「常識」も共通であります. 